\title{
Transformational Leadership and Teacher's Employee Engagement of State Vocational High Schools
}

\author{
IinAsikin, Sylviana Murni, Ma'ruf Akbar
}

\begin{abstract}
Teachers who have high engagement in their work will have positive emotions that direct them to improve their quality through creative and explorative thinking, including making innovations in learning activities. This study aimed to determine the influence of transformational leadership on employee engagement teachers of state vocational high schools. This study uses a quantitative method with a survey approach and uses the sample from 118 teachers (data were collected by personal distribution) in 4 state vocational High Schools in Depok City, West Java Province, who is selected by using Slovin Formula. The result of the study reveals that there is a positive effect the transformational leadership on the employee engagement of state vocational high school teachers.

This indicates with the transformational leadership; the principal can raise and help the level of awareness of the members of the organization to achieve outstanding performance results and employee engagement teachers.
\end{abstract}

\section{Keywords Transformational Leadership; Employee Engagement; Teacher; Vocational School}

\section{INTRODUCTION}

The role of the teacher is very crucial in improving the quality of education, especially vocational education in Indonesia, this is confirmed by the statement of the Minister of Education and Culture, Muhadjir Effendy who admitted, the current condition of Vocational Schools is still far from the expectations, both in terms of quantity and quality, and also 30 percent from the vocational high school graduates are still unemployed (Harian Kompas1), so that teachers need to provide maximum work results. To provide good performance, teachers need a feeling of satisfaction with their work and an enthusiastic attitude to what they do, and to have full involvement both physically and emotionally when doing the work. The feeling of someone who feels enthusiastic, passionate about what he does, is fully involved in his work and feels that he is an important part of his organization, so it will produce a satisfying performance, which is called employee engagement (2). The teachers' employee engagement is involvement and enthusiasm in teaching, where the teachers who have an engagement with their work will seriously place themselves. They voluntarily contribute the intellectual efforts to their duties and show a positive spirit. They feel emotionally connected with their colleagues and actively exchange ideas by discussing how to improve performance. Employee engagement is influenced by the interpretations and responses, received by someone and include the leadership they feel (3), Principals as leader in school, are expected to be able to gather, organize, implement, and control various efforts to achieve the school goals, including fostering understanding and the awareness of the people they lead to believe that the actions are taken with the interests of all members in the organization. Therefore, principals can apply transformational leadership styles, the leaders who inspire and generate extraordinary effort and performance, use their personalities to inspire followers and make their followers much more passionate about the work and organizational goals (4). The ability of school principals to mobilize and empower various components of the school, greatly influence the success of education and learning in schools, so that it is difficult to cultivate with a transformational leadership style that is required to scrutinize the components in the transformational leadership inclusive of the inspirational motivation, ideal influence, individual attention, and intellectual encouragement (5) . If all the aspects of transformational leadership are practiced by the leaders, these aspects will lead to higher employee engagement and employees feel dedicated and have a sense of belonging to their (6).

\section{A. Objectives of the Study}

The objective of this investigation is to obtain correct and reliable comprehension regarding transformational leadership in addition to employee engagement. This study is conducted to know the direct and positive influence of the transformational leadership towards employee engagement.

\section{B. The Hypothesis of the Study}

Based on the existing literature regarding this research, the hypothesis is as follows: There is a direct and positive impact of transformational leadership on employee engagement. 


\section{LITERATURE REVIEW}

\section{A. Employee Engagement}

Employee engagement is vital to drive creativity and ideas and ensure people are actively involved in their work, motivation, and enthusiasm. The perception of employee engagement is a comparatively new concept and was first introduced by William Kahn in 1990, employee engagement as the extraction of organization gives selves to their job roles, commitment, individuals and expressing themselves physically, intellectually and emotionally throughout role execution (7), Organizations anticipate their workers to be enthusiastic, demonstrate initiative, be responsible for their personal career advancement, and commit to high-quality performance benchmarks. They need employees who feel enthusiastic and who are involved with their job (8). Workers who are engaged will have strong feelings, enthusiasm, and focus, which make them more committed to their superiors and try harder in their work (9). Workers who have an engagement with their work will also be more diligent, have initiative, be enthusiastic and focus their energy in achieving organizational goals (10). In general, some things that can increase the engagement of workers, among others, rewards from coworkers, supportive comments and encouragement of feedback from coworkers or superiors on a particular day will increase employee engagement (11)

\section{B. Transformational Leadership}

transformational leaders are those who inspires people to go beyond their personal benefit for the welfare of the company (12). Transformational leadership explains how leaders modify teams or organizations by producing, collaborating, and modelling an idea for the organization or work unit and stimulating employees to struggle for the vision (13). Transformational leaders are leaders who prepare organizational strategies to deal with changes and challenges of the future, through the orientation of vision and charisma that they have and make learning organizations prepared to face challenges in the future (14). Transformational leadership is traditionally divided into four components, namely (1) charisma : Conveys image and sense of undertaking; gain admiration and confidence , (2) inspirational motivation : links high hopes ; expresses essential commitment in simple behaviors, (3) intellectual motivation ; fosters intelligence; rationality; and careful problem resolution , (4) individual attention : gives personal consideration ; treat each employee individually; coaches; advice (15); (16); (17). In terms of manners, transformational leaders boost supporters' perception of the significance of group objectives and enhance the extent to which workers ascertain with such objectives. They also "increase the rewards" of organizational execution by persuading subordinates of the significance of the leader's ideals and foresight, as well as the perils of straying from this image (18).

\section{METHODOLOGY/MATERIALS}

\section{A. Research Approach}

This research uses the quantitative-causal approach as the method of survey research. This approach was chosen to analyze the relationship patterns between variables with the aim to know the direct influences of a set of exogenous variables toward the endogen variable. In this research, transformational leadership is an exogenous variable, and employee engagement is the endogen variable.

\section{B. Participants}

This investigation was conducted in The State Vocational High Schools in Depok City (West Java Province). The analysis unit in this study is the teachers from The State Vocational High Schools. The population is all the teachers in State Vocational Schools which live in Depok with a total of 166 teachers out of 4 schools. The sample of this research was taken by means of random sampling. The samples were selected with the simple random sampling method by choosing the members of the population randomly, ignoring the classes (levels) of each of the population members, bearing in mind that the population is homogenous and has a large number. From the existing population, the number of samples was calculated with the Slovin Formula. Therefore, the sample used in this research is 118 teachers.

\section{Data Collections}

To obtain data in this research, a questionnaire was used for the two variables: transformational leadership (X1), and employee engagement (Y). All the questionnaires were filled in by teachers from The State Vocational High Schools in Depok. The research instrument for the employee engagement variable uses the following indicators: (1) emotional attachment, (2) dedication, and (3) persistence, (4) enthusiasm at work, and (5) initiative. The research instrument contained 36 positive statements. The research instrument for the transformational leadership variable uses the following indicators: 1.) idealized impact, 2.) inspiring motivation, 3.) intelligent stimulation, and, 4.) individual respect. The research instrument contained 35 positive statements. The reliability test of the employee engagement instrument showed an instrument reliability value of alpha Cronbach $\mathrm{r} 11=0,915$. Meanwhile, the transformational leadership had an instrument reliability value of alpha Cronbach $\mathrm{r} 11=0,928$. Therefore, it was concluded that the test for the instruments of employee engagement, and transformational leadership showed that all the instruments had high reliability. Thus, all the instruments could be used in the research to obtain data.

\section{Data Analysis}

This research aims to know the influence of transformational leadership on the teacher's employee engagement. The analysis technique used is the path analysis. 


\section{RESULTS AND FINDINGS}

\section{A. Data Description}

\section{1) Employee Engagement}

The data acquired from the field was treated statistically into a table of a frequency distribution. The figure of classes was calculated as per Sturges' rules. The results show eight classes with a minimum total of 115 and a maximum total of 176. Therefore, the range of scores is 61 . The outcomes of the descriptive statistic calculation show that the average value (mean) of the employee engagement is 145,92 with a standard deviation of 13,76 and a variant value of 189,35 , a median of 146,00, and modus of 156,00. The classification of data can be observed in table 4.1 below.

Table 4.1. Frequency Distribution of Employee Engagement

\begin{tabular}{|c|c|c|c|c|c|c|}
\hline \multirow[b]{2}{*}{ No } & \multirow[b]{2}{*}{$\begin{array}{c}\text { Interval } \\
\text { Class }\end{array}$} & \multicolumn{2}{|c|}{ Limit } & \multicolumn{3}{|c|}{ Frequency } \\
\hline & & Bottom & Top & Absolut & $\begin{array}{c}\text { Cumulat } \\
\text { ve }\end{array}$ & Relative \\
\hline 1 & $115-122$ & 122,5 & 122,5 & 5 & 5 & $4,24 \%$ \\
\hline 2 & $123-130$ & 130,5 & 130,5 & 13 & 18 & $\begin{array}{c}11,02 \\
\%\end{array}$ \\
\hline 3 & $131-138$ & 138,5 & 138,5 & 19 & 37 & $\begin{array}{c}16,10 \\
\%\end{array}$ \\
\hline 4 & $139-146$ & 146,5 & 146,5 & 22 & 59 & $\begin{array}{c}18,64 \\
\%\end{array}$ \\
\hline 5 & $147-154$ & 154,5 & 154,5 & 25 & 84 & $\begin{array}{c}21,19 \\
\%\end{array}$ \\
\hline 6 & $155-162$ & 162,5 & 162,5 & 19 & 103 & $\begin{array}{c}16,10 \\
\%\end{array}$ \\
\hline 7 & $163-170$ & 170,5 & 170,5 & 11 & 114 & $9,32 \%$ \\
\hline 8 & $171-178$ & 178,5 & 178,5 & $\begin{array}{c}4 \\
118 \\
\end{array}$ & 118 & $\begin{array}{c}3,39 \% \\
100 \% \\
\end{array}$ \\
\hline
\end{tabular}

\section{2) Transformational Leadership}

The figures acquired from the field was treated statistically into a table of a frequency distribution. The figure of classes was calculated as per Sturges' rules. The results show eight classes with a minimum score of 115 and a maximum score of 175 . Therefore, the range of scores is 60 . The outcomes of the descriptive statistic calculation show that the average value (mean) of the transformational leadership is 144,81 with a standard deviation of 13,62 variant value of 185,41 , the median of 145,00 , and modus of 151,00 . The classification of data can be observed in table 4.1 below.

Table 4.1. Frequency Distribution of Transformational Leadership

\begin{tabular}{|c|c|c|c|c|c|c|}
\hline \multirow[b]{2}{*}{ No } & \multirow[b]{2}{*}{$\begin{array}{c}\text { Interval } \\
\text { Class }\end{array}$} & \multicolumn{2}{|c|}{ Limit } & \multicolumn{3}{|c|}{ Frequency } \\
\hline & & Bottom & Top & Absolut & $\begin{array}{c}\text { Cumula } \\
\text { ve }\end{array}$ & Rela \\
\hline 1 & $115-122$ & 114,5 & 122,5 & 6 & 6 & $5,08 \%$ \\
\hline 2 & $123-130$ & 122,5 & 130,5 & 13 & 19 & $\%$ \\
\hline 3 & $131-138$ & 130,5 & 138,5 & & 37 & $\begin{array}{c}15,25 \\
\%\end{array}$ \\
\hline 4 & $139-146$ & 138,5 & 146,5 & 27 & 64 & $\begin{array}{c}22,88 \\
\%\end{array}$ \\
\hline 5 & $147-154$ & 146,5 & 154,5 & 26 & 90 & $\begin{array}{c}22,03 \\
\%\end{array}$ \\
\hline
\end{tabular}

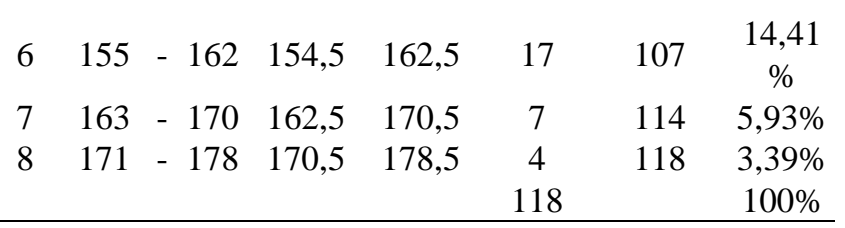

B. Test of Analytic Requirements

1) Normality Test

The normality test was done using the Liliefors technique. The H0 criteria which state that the scores do not have a normal distribution is that if Lcount is less than Stable. Normality Test for Estimated Errors of Regression of Y over $\mathrm{X} 1$ the results show that Lcount $=0,0290$. This value is less than Ltabel $(\mathrm{n}=118 ; \alpha=0,05)$ which is 0,0816 . Bearing in mind that Lcount is less than Ltabel, the distribution of data for employee engagement over transformational leadership forms a normal curve. Centered on those results, it can be determined that the zero hypotheses $(\mathrm{H} 0)$ which state that the sample comes from the population has a normal distribution cannot be overruled. In other words, all the chosen samples come from a population that has a normal distribution. Populations that had a normal distribution.

2) Significance and Linearity of Regression Test

Before using the regression to derive a conclusion in testing the hypothesis, the regression model is tested for significance and linearity using the $\mathrm{F}$ test in the ANOVA table. The criteria for the significance and linearity test of the regression model is as follows:

Significant regression: Fcount $\geq$ Ftable on the regression line

Linear regression: Fcount $<$ Ftable on the tuna line is a match.

The next step is conducting a correlational analysis by observing the level and significance of the relationship between the exogenous variable and endogen variable pairs. Test of the Significance and Linearity of the Regression Model for employee engagement over transformational leadership, the results of the calculation for the regression model between employee engagement over transformational leadership shows that the regression constant $\mathrm{a}=56,753$ and the regression coefficient $b=0,616$. Therefore, the relationship of the simple regression model is $\overline{\mathrm{Y}}=56,753+$ $0,616 \mathrm{X} 1$. The regression equation showed significant meaning at a 5\% significance level. This regression equation can be interpreted that the change in one unit of transformational leadership score will be followed by a change in employee engagement score of 0.616 units in the constant 56,753 . Before the regression model is analyzed further and used to derive a conclusion, a test for the significance and linearity of the regression model is done. The results can be observed in the ANOVA table as shown in table 4.5 below. 
Table 4.5 ANOVA on the Test for Significance and Linearity of the Regression Model ${ }^{\widehat{Y}}=56,753+0,616$ X1

\begin{tabular}{|c|c|c|c|c|c|c|}
\hline \multirow{2}{*}{$\begin{array}{c}\begin{array}{r}\text { Source o } \\
\text { Variant }\end{array} \\
\text { Total } \\
\end{array}$} & \multirow{2}{*}{$\frac{d k}{118}$} & \multirow{2}{*}{\multicolumn{2}{|c|}{$\begin{array}{cc}\begin{array}{c}\text { SquareT T } \\
\text { tal (JK) }\end{array} & \begin{array}{c}\text { Average } \\
\text { Square Tots } \\
\text { (RJK) }\end{array} \\
8733 & \end{array}$}} & $\mathbf{F}_{\text {count }}$ & \multicolumn{2}{|c|}{$\begin{array}{c}\mathrm{F}_{\text {table }} \\
\alpha={ }^{\alpha, 05} \\
\alpha=0,0\end{array}$} \\
\hline & & & & \multirow{4}{*}{$\begin{array}{c}68,51 \\
* *\end{array}$} & \multirow[b]{3}{*}{3,92} & \multirow[b]{3}{*}{6,86} \\
\hline $\begin{array}{c}\text { Regressio } \\
\text { a }\end{array}$ & 1 & $\begin{array}{c}2512660 \\
9\end{array}$ & & & & \\
\hline $\begin{array}{c}\text { Regressio } \\
\text { b/a }\end{array}$ & 1 & 8226,00 & 8226,00 & & & \\
\hline Residue & 116 & 13928,31 & 120,07 & & & \\
\hline Match & 39 & 5195,67 & 133,222 & $1,175^{\mathrm{n}}$ & 1,56 & 1,87 \\
\hline Error & 77 & 8732,64 & 113,411 & & & \\
\hline
\end{tabular}

Keterangan:

**: Regression is very significant $(68,51>6,86$ pada $\alpha=$ $0,01)$

ns : Regression is linear $(1,175<1,56$ pada $\alpha=0,05)$

$\mathrm{dk}$ : Degree of freedom

JK : Square Total

RJK : Average square total

The regression model $\overline{\mathrm{Y}}=56,753+0,616 \mathrm{X} 1$ for the significance test shows that Fcount 68,51is more than Ftable $(0,01 ; 1: 116) 6,86$ for $\alpha=0,01$. Because Fcount $>$ Ftable, the regression is very significant. The linearity test shows that Fcount is 1,175 which is less than Ftable $(0,05 ; 39: 77)$ which is 1,56 for $\alpha=0,05$. Because Fcount $<$ Ftable, the distributions of dots which are estimated to form a linear line can be accepted.

\section{3) Hypothesis}

The statistical hypothesis tested was a positive direct influence of transformational leadership (X) towards employee engagement (Y).

Statistically:

H0: $\beta \mathrm{yx} \leq 0$

$\mathrm{H} 1: \beta \mathrm{yx}>0$

Based on the calculations from the path analysis, the direct influence transformational leader towards employee engagement, the coefficient value is 0,280 and tcount $=3,26$. The value of ttable for $\alpha=0,05$ is 1,98 . Therefore, because the value of tcount is more than the value of table, $\mathrm{H} 0$ is rejected and $\mathrm{H} 1$ is accepted. In other words, transformational leadership has a direct influence on employee engagement. The analysis of the hypothesis shows that transformational leadership has a direct and positive influence on employee engagement. Thus, it can be concluded that transformational leadership influenced directly and positively by employee engagement. Increasing the role of transformational be able to increase a teacher's employee engagement. The results of this study were supported with Albrecht's opinion which states that this type of leadership style, which resembles the idealized influence, and individual consideration dimension of transformational leadership, had an especially positive effect on engagement in "active work" contexts (19).

\section{4) Discussion of Research Results}

Based on the literature review and empirical study above, results are discussed below to conduct a synthesis between the theory and the empirical findings. The detailed discussion of the analysis and hypothesis tests are elaborated below:

The hypothesis test concludes into a direct and positive influence of transformational leadership towards employee engagement. Based on the calculations from the path analysis, the direct impact of transformational leader towards employee engagement, the coefficient value is 0,280 and tcount $=3,26$. The value of ttable for $\alpha=0,05$ is 1,98 . Therefore, because the value of tcount is more than the value of ttable, H0 is overruled and H1 is acknowledged. In other words, transformational leadership has a direct impact on employee engagement. Previous research results demonstrate that there is a significant positive influence of transformational leadership towards employee engagement (20). Through a transformational leadership style, principals can grow and increase the optimism and work engagement of teachers (21), one of them is by creating a conducive work environment. Transformational leadership can develop employees to become more engaged, especially if they can make them participate with organizational goals. In addition, the engagement of workers significantly affects loyalty and commitment when leaders succeed in adjusting transformational leadership (22). Transformational leadership can be considered as one of the best leadership styles that influence subordinates through development and promotion, and by creating honest feelings will make them act beyond agreed expectations. And because self-efficacy refers to an individual's trust in one's own abilities, it can be said that the transformational leadership style makes the person have a positive outlook on himself and also uses the skills he has while working. Employees who have high self-efficacy will strive to the fullest and feel engage and responsible for the success of the organization (23).

\section{CONCLUSIONS}

Based on the results of the research data and the analysis which has been discussed with all the requirements of data analysis which include the linearity test and validity of regression, the conclusions derived are as follows: transformational leadership has a direct and positive impact on employee engagement. This suggests that an increase in the role of transformational leadership causes an increase in the employee engagement of State Vocational High School teachers.

\section{A. Implications}

Efforts to increase employee engagement through transformational leadership is possible by increasing the role of transformational leadership. This effort can be carried out by various activities: trying to give full attention to the teachers, offer funding in getting job done, inspire teacher creativity, push the teacher to think of new ways, fulfill the socio-emotional needs of teachers by implementing a system of reward and punishment based on teacher performance, and increase teacher commitment so that they care and take part in thinking about school development with innovative ideas. 


\section{B. Recommendations}

- The principal, as a personification figure in the school, must have an understanding related to the purpose of education, has an idea of the future and has the ability to actualize all of its potentials into a synergistic power in order to achieve educational goals, in addition, as a manager, it should have competence in preparing school planning and development systemically, competent in mobilizing all school personnel so they sincerely worked hard to achieve the school's institutional goals, competent in fostering teacher professional skills so that they are more skilled in managing the learning process, and competent in conducting monitoring and evaluation so that no single component of the school system does not function optimally.

- The teachers, should have high employee engagement, by increasing new knowledge by participating in professional competency development forums, besides that the teacher should be dedicated to developing creativity in school, by creating creative learning, which gives students the freedom to explore and create a comfortable classroom climate so that the education process in schools can truly produce graduates who have high creativity.

\section{Limitations and Future Research}

Researchers may regard this study as a reference in future Aresearch related to teachers' employee engagement because the scope of this study is limited to transformational leadership.

\section{REFERENCES}

[1] Harian Kompas. 2017.

[2] Colan LJ. Engaging the Hearts and Minds of All of Your Employees. United States: McGraw-hill; 2009.

[3] Evelyn DA, Elegwa M. The Effect Transformational Leadership on Employee Engagement. Business Management and Economics. 2015;3 (I).

[4] Schermerhorn JR, Bachrach DG. Introduction to Management. River Street Hoboken: John Wiley \& Sons; 2015.

[5] Hayati D, Charkhabi M, Naami AZ. The Relationship between Transformational Leadership and Work Engagement in Governmental Hospital Nurses: A Survey Study. Springer Plus. 2014:1-7.

[6] Raja MW. Does Transformational Leadership Leads to Higher Employee Work Engagement? Academic Research Business and Social Science. 2012; II/1:7.

[7] Kinicki A, Fugate M. Organizational Behavior, A Practical, Problem Solving Approach. New York: McGraw-Hill Education; 2016. 52 p.

[8] Bohlander GW, Snell SA. Principles of Human Resource Management. Sixteenth International Edition ed. South Western: Cengage Learning; 2013. 151. p.

[9] Dessler G. Human Resource Management. USA: Pearson Education; 2013. 326 p.

[10] Macey WH, Schneider B, Barbara KM, Young SA. Employee Engagement: Tools for Analysis, Practice and Competitive Advantage. UK: Wiley- Blackwell; 2009. 7 p.

[11] Schaufeli WB, Baker AP. Work Engagement A Handbook of Essential Theory and Research. USA Psychology Press; 2010.

[12] Snell Bd. Managemennt, Leading and Collaborating in Competitive World. New York: McGraw-Hill; 2015.

[13] McShane, Glinow V. Organizational Behavior, Emerging Knowledge and Practice for The Real World. New York: McGraw-Hill; 2010.

[14] Newstrom JW. Organizational Behavior, Human Behavior at Work. New York: McGraw-Hill; 2015.
[15] Luthans F. Organizational Behavior. Twelfth Edition ed. New York: McGraw-Hill; 2011.

[16] Slocum JW, Hellriegel D. Organizational Behavior. Mason: South Western 2011

[17] Bass BM, Riggio RE. Transformasional Leadership. New Jersey: Lawrence Erlbaum; 2006.

[18] Wagner JA, Hollenbeck JR. Organizational Behavior, Securing Competitive Advantage. New York: Routledge; 2010.

[19] Albrecht SL. Handbook of Employee Engagement. Cheltenham, UK: Edward Elgar Publishing; 2010.

[20] Kopperud KH, Martinsen O, Humborstad SIW. Engaging Leaders in The Eyes of The Beholder: on The Relationship between Transformational Leadership, Work Engagagement, Service Climate, and Self-Other Agreement. Journal of Leadership and Organizational Studies. 2014;21 (1):29-42.

[21] Tims M, Bakker AB, Xanthopoulou D. Do Transformational Leaders Enhance Their Followers"s Work Engagement? The Leadership Quarterly. 2011:121-31.

[22] Mansor ZD, Mun CP, Farhana BSN, Nasuha WA, Tarmizi WM Influence of Transformation Leadership Style on Employee Engagement Among Generation Y, Journal of economics and Management Engineering. 2017; Vol.11.

[23] Chaudari R, Rangnekar S, Barua MK. Impact of Occupational Self Efficacy on Employee Engagement an Indian Perspective. Journal of the Indian Academy of Applied Psychology 2012;

\section{AUTHORS PROFILE}

I am IinAsikin, currently affiliated with Universitas Negeri Jakarta, Indonesia. My area of interest is Leadership. iin.gp13@gmail.com

My good name is SylvianaMurni and my affiliation is Universitas Negeri Jakarta, Indonesia. My area of interest is vocational training and Leadership.

I am Ma'ruf Akbar, affiliated with Universitas Negeri Jakarta, Indonesia. 